\title{
Characterization of Emergence Flows of Volunteer Corn as Function of the Type of Harvest Grain Loss
}

\author{
Alexandre Ferreira da Silva ${ }^{1}$, Fernando Storniolo Adegas $^{2} \&$ Germani Concenço $^{3}$ \\ ${ }^{1}$ Embrapa Milho e Sorgo, Sete Lagoas, Minas Gerais, Brazil \\ ${ }^{2}$ Embrapa Soja, Londrina, Paraná, Brazil \\ ${ }^{3}$ Embrapa Clima Temperado, Pelotas, Rio Grande do Sul, Brazil \\ Correspondence: Alexandre Ferreira da Silva, Embrapa Milho e Sorgo, Sete Lagoas, Minas Gerais, 35701970, \\ Brazil. Tel: 55-031-3027-1251. E-mail: alexandre.ferreira@embrapa.br
}

Received: February 9, 2018

Accepted: March 12, $2018 \quad$ Online Published: April 15, 2018

doi:10.5539/jas.v10n5p258

URL: https://doi.org/10.5539/jas.v10n5p258

\begin{abstract}
Volunteer corn resistant to glyphosate is constant as weed in soybeans planted in succession. This work aimed to identify the emergence flows of volunteer corn plants in the period of time from the harvest of corn planted following soybean (autumn corn) to the plenty establishment of the canopy of the following soybean crop (summer soybean), as a function of different types of propagules generated by preceding corn harvest losses. Four field experiments were carried out in 2013 and 2014, at a Cerrado location (Sinop, MT) and a subtropical location (Londrina, PR), Brazil. Treatments included the distribution of corn crop residues (factor "A") either on soil surface or incorporated into superficial soil layers. Four types of propagules (factor "B") were characterized as ears with whole husk; ears with half husk; broken ears, no husk; and loose grains. The density of emerged plants was recorded fortnightly between August and December. When partially incorporated into soil, propagules generate an increased density of emerged plants as compared to the surface deposition treatments. The main sources of volunteer plants, in descending order of importance, were: (1) loose grains, (2) broken ears, (3) ears with damaged husk, and (4) ears with intact husk. Ears emerged later compared to loose grains or broken ears. Climatic conditions influence the emergence pattern. For the climate of (Savannah-like) Cerrado, the beginning of the rainy season is preponderant for the start of corn emergence. Under subtropical climatic conditions, mild low temperatures, associated or not to rainfall, determine the emergence peaks.
\end{abstract}

Keywords: emergence timing, corn propagules, glyphosate-resistant, intensive production systems

\section{Introduction}

The most important crop rotation in grain-producing areas of Brazil is the cultivation of soybeans in spring/summer, immediately followed by corn planted in summer/fall. Soybean resistant to glyphosate (GR) was officially approved in Brazil to be planted in 2006, and the GR corn in 2010. Since their commercialization in Brazil, GR corn and soybean were rapidly adopted by growers as they make weed management easier. In 2017, more than $70 \%$ of corn and $90 \%$ of soyeban planted were GR. After the approval of the GR corn it in fact became itself one of the main weeds to be controlled into GR soybean fields. Glyphosate, which was previously the main tool to provide control of volunteer corn in GR soybeans, has become a useless tool in its control, due to the insertion of the resistance gene to this herbicide in corn. Volunteer plants come from grains lost during corn harvest in fall/winter, and start to emerge with the first rain events at or right after soybean sowing, in the next planting season. Volunteer corn plants are very skilled competitors in depleting natural resources such as water, light and nutrients. Where there is no control of volunteer corn plants, soybean yield losses of approximately $25 \%$ is expected with volunteer corn densities of 1 plant $\mathrm{m}^{-2}$ (Alms et al., 2016). The degree of interference of volunteer corn on soybean depends both on its density and its emergence timing. Marquardt et al (2012) reported that $0.5-16$ corn plants $\mathrm{m}^{-2}$ caused $10-40 \%$ of reduction in soybean grain yield. However, the soybean yield was not affected when corn, at these densities, emerged later compared to soybean. In addition to competing for environmental resources, volunteer corn can serve as a host, or green bridge, for pests and diseases, causing even more losses to soybeans. Pests which affect several crops as armyworm (Spodoptera frugiperda), may migrate from volunteer corn to soybean and impact its plant stand and productivity (Silva et al., 
2017). The presence of volunteer corn during fallow may also contribute do increases in the population of soybean cyst nematode (Heteroda glycines) (Fonte).

Control of volunteer corn is, therefore, fundamental for full expression of crop yields in successional crops such as soybeans. Reducing crop losses through better adjustment of combines and harvesting at the appropriate time help to decrease the emergence of volunteer corn plants (Shauck et al., 2010). Harvesting losses create a variety of propagules that may lead to the emergence of volunteer corn in successional soybeans, such as grains detached from ears, damaged ears with and without husk, as well as whole and broken ears. Such remaining propagules can be either deposited on the soil surface or partially incorporated into soil at shallow depths, as a result of the machinery traffic during harvest, sowing or pesticide applications.

Due to the prevailing no-tillage cropping systems adopted by Brazilian farmers, weed management relies primarily on the use of herbicides. Although the soil tillage may be considered as tool to manage volunteer corn, it is undesirable in Brazilian environmental conditions where the dry matter degradation rate is naturally high; soil tillage would result in chopping of the mulching and its partial incorporation into soil, increasing the degradation rate (Busari et al., 2015).

Control of volunteer plants emerged from ear segments, unlike those emerged from scattered grains, tends to be more troublesome because seeds adhered to the ear will emerge unevenly in time, what can result in several flows along the soybean cycle (Petter et al., 2015). Volunteer corn emerged from grains still attached to ears predominate in areas where lodging and/or breakage of plants occurs and; in this situation, volunteer corn occurs in clumps with high density of plants at specific spots into the field (Deen et al., 2006). Thus, it is to be expected that harvest losses as ear segments tend to to cause more damage to soybean performance than the interference caused by individual plants originated from grains detached from the ear. López-Ovejero et al. (2016) reported yield losses between 18 and $70 \%$ in soybean yield when the corn residues varied between one and four ear segments per $\mathrm{m}^{2}$.

The control of glyphosate-tolerant volunteer corn in GR soybeans is primarily performed with the use of post-emergence herbicides of the acetyl-coenzyme-A carboxylase inhibitors (ACCase), since the most pre-emergence soybean herbicides provide inefficient control of volunteer corn (Chahal et al., 2014; Marquart \& Johnson, 2013). Controlling volunteer corn at the right timing also exerts a great influence on soybean yield. Volunteer corn emerging later in the season cause lower soybean yield loss compared to the plants emerged during early soybean growth stages (Chahal \& Jhala, 2016). In order to establish an efficient management strategy, it is therefore relevant to understand the dynamics of the emergence flow and the control strategy that best applies to each reality.

This work aimed to identify the emergence flows of volunteer corn plants in the period of time from the harvest of corn planted following soybean (autumn corn) to the plenty establishment of the canopy of the following soybean crop (summer soybean), as a function of different types of propagules generated by preceding corn harvest losses.

\section{Materials and Methods}

Field experiments were conducted at two locations during 2013 and 2014. The first experiment was conducted at

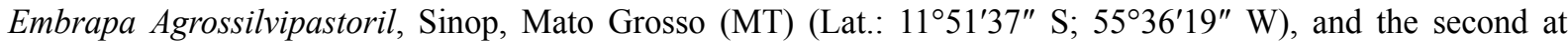

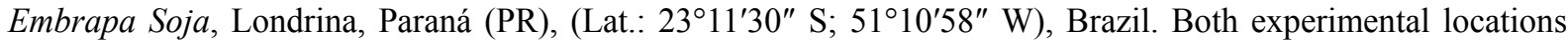
have Clay texture soil (Sinop-MT: pH 5.2, 34\% sand, $22 \%$ silt, $44 \%$ clay and $1.9 \%$ organic matter-OM; Londrina-PR: $\mathrm{pH} 5.6,77 \%$ clay, $7 \%$ silt, $16 \%$ sand and 2.7\% OM). Mean climatic inputs recorded throughout the experiments are presented in the respective figures, along with emergence of volunteer corn seedlings. The treatments were composed by four different corn propagule types (factor "B"), either distributed on soil surface or partially incorporated into soil (factor "A") (Table 1). Corn propagules used at the present study were collected at the time of corn harvest, on neighboring fields, and immediately deposited/planted (depending on the treatment) in the area of the experiment. 
Table 1. Treatments screened for volunteer emergence of corn plants in the period preceding planting, and during initial development of soybean, at Sinop-MT and at Londrina-PR, Brazil, in 2013 and 2014

\begin{tabular}{llll}
\hline & Arranged on soil surface & & Partially incorporated into soil \\
\hline T1. & Ear with whole husk & T5. & Ear with whole husk \\
T2. & Ear with half husk & T6. & Ear with half husk \\
T3. & Broken ears, no husk & T7. & Broken ears, no husk \\
T4. & Loose grains & T8. & Loose grains \\
\hline
\end{tabular}

The "partially incorporated" treatments (T5-T7) consisted on the shallow incorporation of one half of each ear into soil (treatments with ears), or grain coverage with a layer of $2 \mathrm{~cm}$ of soil (treatments with spare grains) (T8), simulating the compaction caused by the combine wheels. The plots consisted of a $1 \mathrm{~m}^{2}$ area, where the different types of propagules were evenly distributed, with four replications. Each experimental plot comprised six ears of corn or $0.5 \mathrm{~kg}$ of grains (corresponding to the average amount of grains from six corn ears), according to the treatment (Table 1). Considering that the present study aimed to assess the behavior of emergence flow of corn, a big amount of grains was supplied per square meter of the plots aiming to give higher reliability to the dataset.

The experiments were carried out from August to December in both years, during the period between corn harvest and the establishment of the successional soybean canopy. Both experiments were installed in traditionally cropped areas, with no corn or soybean planting in the previous two years. Areas were kept free from weeds during the course of the experiments by a burndown application with glyphosate prior to implantation and regular applications of paraquat dose of $600 \mathrm{~g} \mathrm{ha}^{-1}$, for controlling the volunteer corn flows after each evaluation. All herbicide applications were always carried out with a $\mathrm{CO}_{2}$ pressurized sprayer, coupled to an application bar with nozzles 110.02 , spaced in $0.50 \mathrm{~m}$, regulated for a spraying volume of $120 \mathrm{~L} \mathrm{ha}^{-1}$. Fortnightly counts of the density of corn seedlings emerged per plot were carried out.

Data were analyzed by descriptive statistics. In the first step of the analysis, the emergence of corn seedlings was correlated to available local climatic parameters for each location: mean air temperature $\left({ }^{\circ} \mathrm{C}\right)$ for Paraná; mean maximum soil temperature $\left({ }^{\circ} \mathrm{C}\right)$ for Mato Grosso; and relative air humidity $(\%)$ and rainfall $(\mathrm{mm})$ for both locations.

Corn emergence was described by bar graphs for the fortnight periods between the first half of August and the second half of December. On the bar graph, the climatic parameters were illustrated by a smoothed line, from climatic data obtained from local automatic climatic stations, as average values for ten-days periods (three means per month). The climatic parameter curve was smoothed by the Loess method (Cleveland \& Devlin, 1988), by using the quadratic model, in order to better characterize the local microclimate, presenting $95 \%$ confidence intervals. The correlation of corn emergence to the climatic parameters was run separately for each year of the experiment.

The second step of the analysis consisted on analyzing emergence patterns of corn seedling for each of the two years (2013 and 2014). The third step consisted on the characterization of the emergence of volunteer corn as a function of a period of the year $\left(1^{\text {st }}\right.$ half of August $-2^{\text {nd }}$ half of December $)$, considering the different treatments (Table 1). For the second and third steps, the emergence data was smoothed by the Loess quadratic model (Cleveland \& Devlin, 1988), and the curves were compared on the basis of their respective $95 \%$ confidence intervals (Cumming et al., 2007). The curves were considered distinct in sections where their respective confidence intervals did not overlap.

The fourth step of the analysis consisted on the characterization of each of the four crop loss types (factor "B") as a function of soil deposition (factor "A"), and the results were organized in circular percent graphs. All the analyzes were performed in the statistical software "R" (R Core Team, 2016), using functions available in the base and ggplot2 packages.

\section{Results and Discussion}

The emergence flows vary depending on the type of propagule and on climatic conditions specific to each growing environment. The results are discussed separately according to the locality of the trial, due to the edaphoclimatic differences between these regions. 


\subsection{Sinop-MT}

When propagules were deposited in the soil surface (T1-T4), individual corn grains provided the highest emergence (40-100\%) compared to other propagules (0-23\%) (Figure 1). There was an intense emergence flow in the second half of October, mainly due to the onset of regular rainfall, which coincides with the beginning of soybean sowing in the region. This result indicates that a large part of the emergence flow of volunteer corn concentrates either prior to soybean sowing or simultaneously to its emergence.
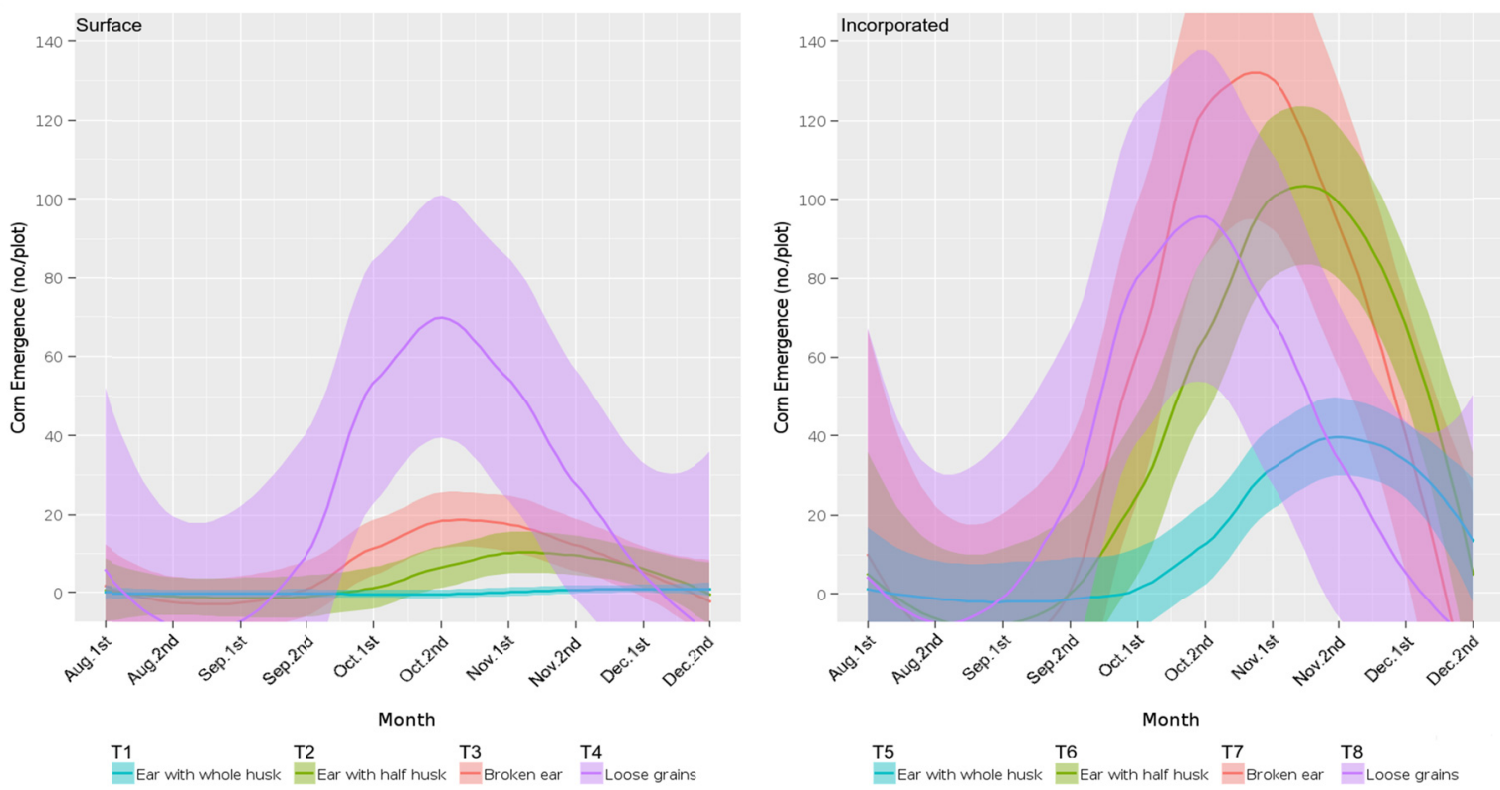

Figure 1. Dynamics of the emergence flux of volunteer corn, mean of 2013 and 2014, as a function of both disposition in soil (on surface, or partially incorporated) and the type of harvest loss. Sinop-MT, Brazil. 95\% confidence intervals are presented

In field conditions, this scenario indicates a need for an additional grass herbicide application to provide control of remaining GR corn plants prior to soybean sowing, even after burndown with glyphosate. Alternatively, the herbicide may be applied early at the start of soybean development, to reduce the level of interference from the volunteer plants. Late applications of herbicides imply in a longer period of coexistence of volunteer plants with soybean, which tends to decrease crop yield (Chahal \& Jhala, 2016). Ears with intact husk were the type of propagule that provided the lowest density of emerged plants.

Propagules of volunteer corn partially incorporated into soil (T5-T8) led to an increased density of emerged corn plants as compared to those left on soil surface (T1-T4; Figure 1). Increased emergence flow is probably related to grain protection against excessive heat and low air humidity, typical climatic conditions for that region in the period between corn harvest and soybean sowing (Souza et al., 2013). Most likely, such climatic conditions contributed for dehydration of many of the grains deposited on soil surface, resulting in embryo death and, therefore in a reduced number of volunteer plants. Loose grains (T4, T8) and broken ears (T3, T7) emerged in earlier peaks as compared to ears with whole (T1; T5) or half husks (T2; T6). This pattern indicates the probable occurrence of different emergence flows of volunteer corn throughout the soybean cycle, what could probably lead to the need of more than one herbicide application during the soybean summer cycle. The germination of grains adhered to ears is characterized by a group of plants (cluster), that tend to emerge simultaneously, which can intensify the competition with soybean. Therefore, volunteer corn plants derived from ears potentially cause higher levels of losses than individual scattered plants (Chahal \& Jhala, 2016).

The emergence of propagules varies depending on their deposition in soil (Figure 2). When the distribution is superficial, grains detached from ears represent $65 \%$ of the total emerged plants. On the other hand, when crop residues are incorporated into shallow layers of soil, the density of emerged plants is evenly distributed among different types of propagules. This fact indicates that the incorporation of grains in soil tends to stimulate the overall germination, facilitating the increase in density of volunteer plants. The highest emergence levels 
observed with incorporation may be associated to the buffer effect against adverse climatic conditions, preserving the viability of the seed embryo. Thus, it is expected that soil tillage after corn harvest may contribute to the greater emergence of volunteer plants, due to the incorporation of corn seeds into the soil superficial layer.

Surface

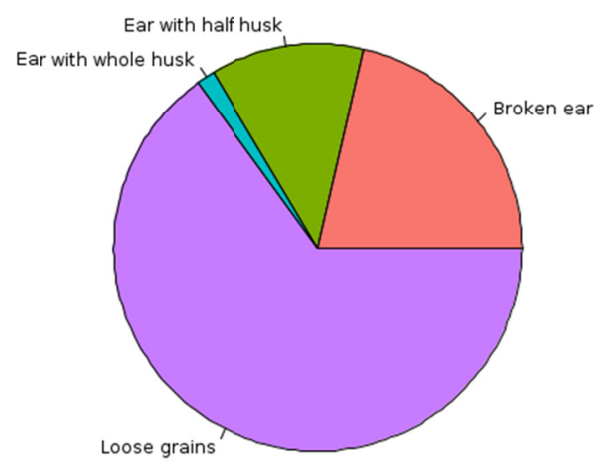

Incorporated

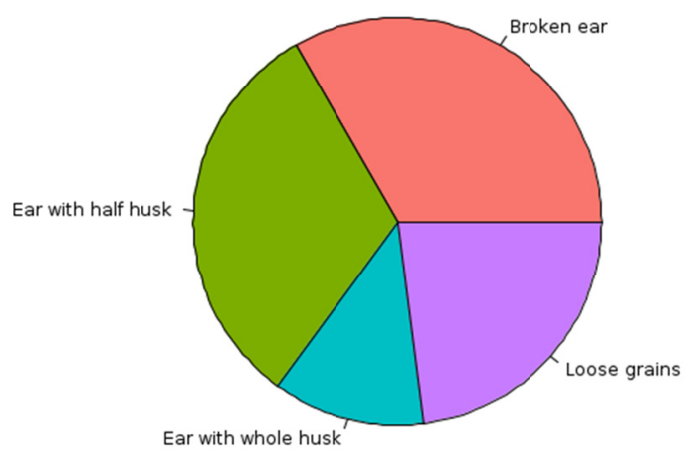

Figure 2. Mean proportion of volunteer corn seedlings, as function of both the disposition in soil (on surface, or partially incorporated) and the type of harvest loss. Sinop-MT, Brazil

A similar trend for the emergence flow was found for both years (Figure 3). In general, seedlings started to emerge by the second half of September, the period of the first rainfalls, with an emergence peak at the second half of October, and subsequent decrease over the evaluation period. Volunteer corn tends to be a problem, especially during the initial period of soybean development, before crop canopy formation (Chahal \& Jhala, 2016). Although the dynamics of the emergence flow was similar for both years, the density of plants emerged in 2014 was higher than in 2013 , what is likely correlated to specific climatic conditions of each agricultural year (Figure 3).

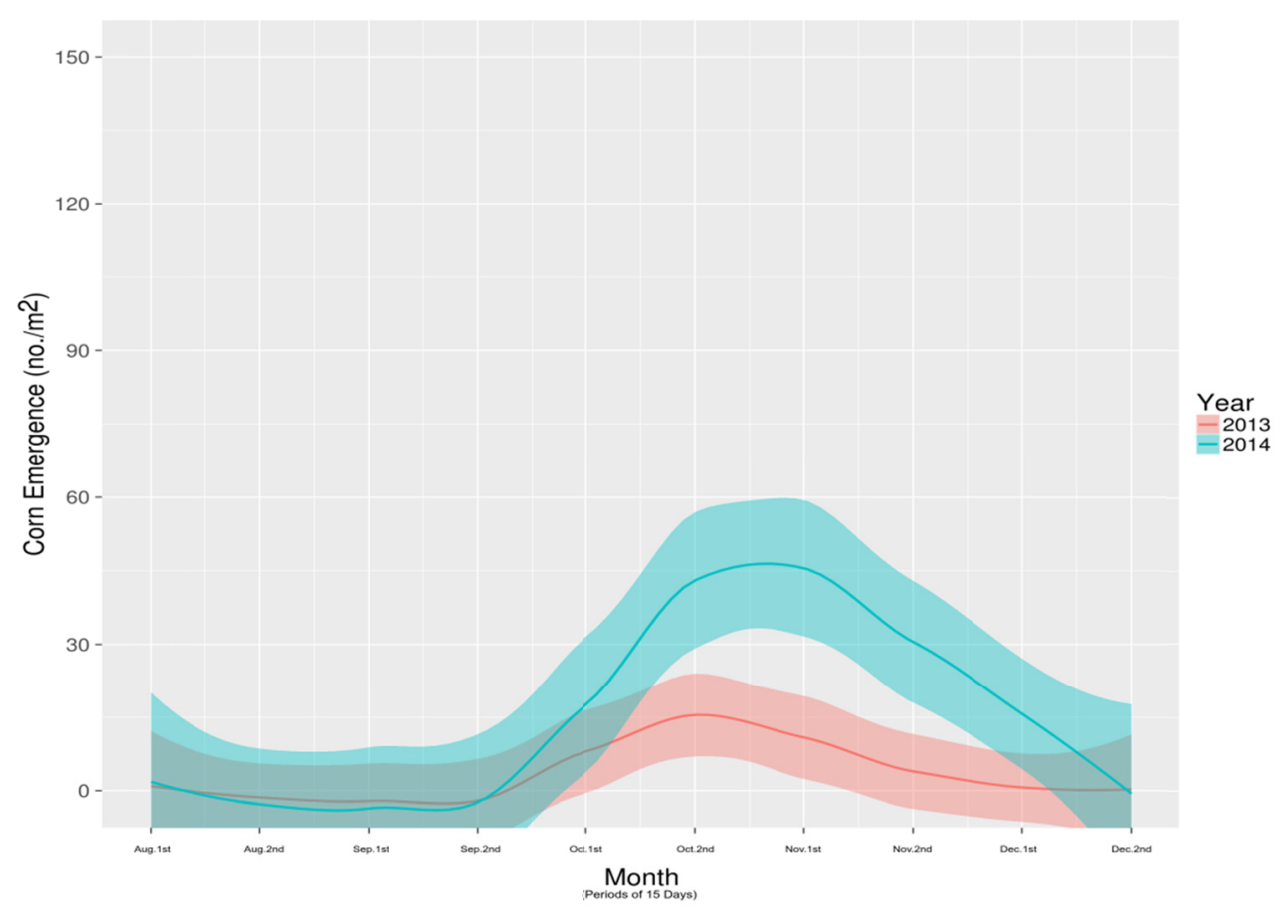

Figure 3. Dynamics of the emergence flux of volunteer corn, by year. Means of the disposition in soil and the type of harvest loss. Sinop-MT, Brazil. 95\% confidence intervals are presented 
Among the climatic factors that may have affected the emergence flow during the evaluation period, rainfall, air humidity and soil temperature can be highlighted. In 2013, the emergence flow of volunteer corn was concentrated in the second half of October, period when $\approx 80 \%$ of total number of plants emerged. On the other hand, in 2014, the emergence flow was more evenly distributed throughout the evaluation period, and concentrated mainly between the second half of October and the first half of November, with $40 \%$ and $30 \%$, respectively, of the total number of emerged plants (Figure 4).
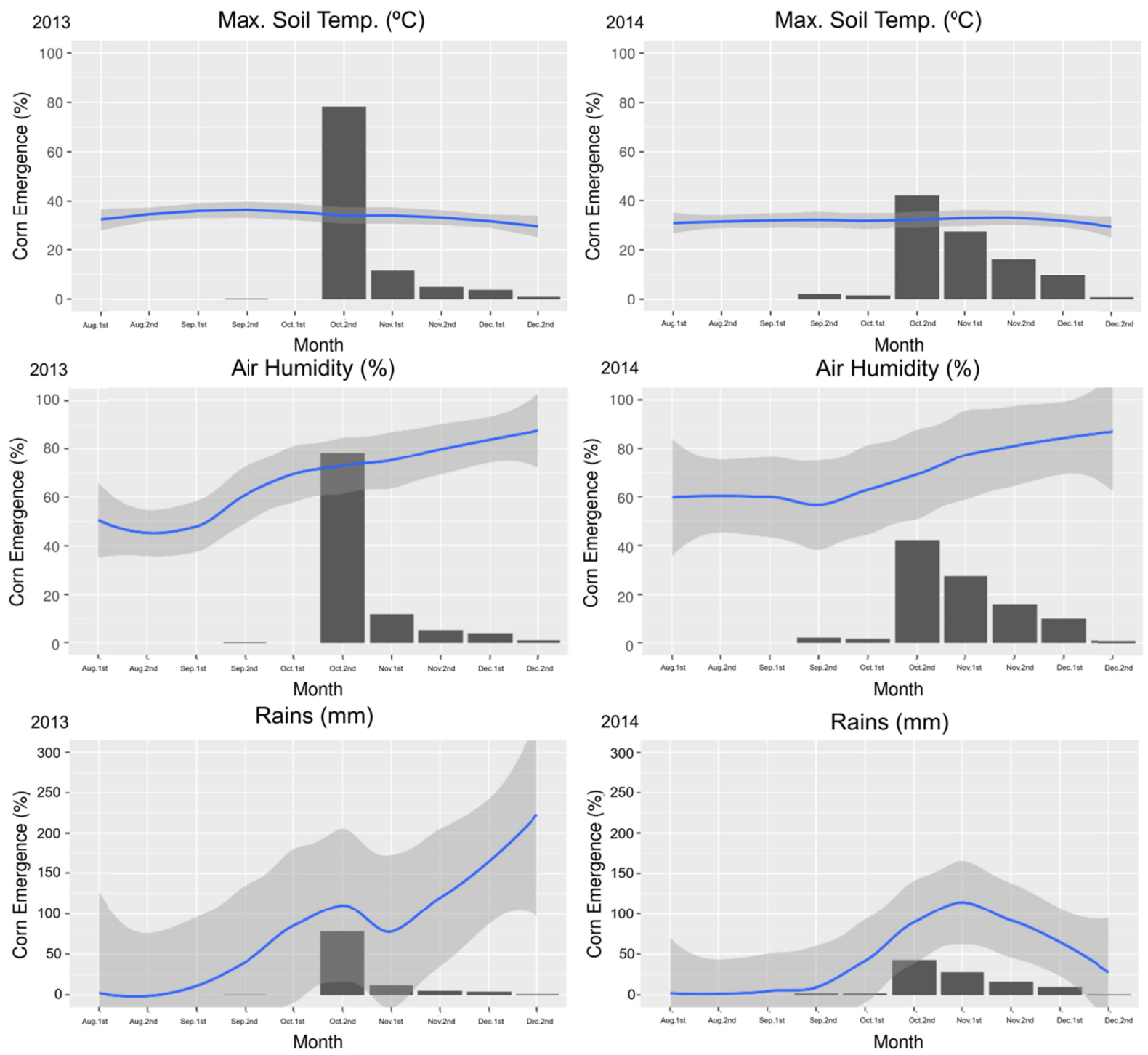

Figure 4. Dynamics of the emergence flux of volunteer corn (-bars), by year, as function of the environmental parameter. Means of the disposition in soil and the type of harvest loss. The behavior of the climatic parameters for the year is presented by a regression smoothed by the Loess method, with a $95 \%$ confidence interval obtained from the 10-day period for every data of the graph (three points of mean data per month). Sinop-MT, Brazil

Although there is no significant variation in the averages of the maximum soil temperatures between 2013 and 2014, the period between August and the first half of October 2013 averaged maximum temperatures $4{ }^{\circ} \mathrm{C}$ higher than 2014. The first year was also characterized by lower air humidity. Although temperatures did not result in significant interference, high temperatures associated with low air humidity observed in 2013 may have contributed to less viability of seed embryos due to unfavorable climatic conditions.

The rainy season in 2013 started effectively in the first half of October, unlike 2014, when this period started fifteen days later. These climatic changes contributed to the fact that the density of plants emerged in 2014 was 
higher and delayed in 15 days compared to 2013, where emergence started in the first half of October, in a traditional Cerrado (Savannah-like) climate. For the Cerrado region of Brazil, the prevailing climatic factor that triggered the emergence of volunteer corn plants was the onset of rains (Figure 4). Seeds incorporated into soil were more responsive to moisture, with the highest density of volunteer corn plants emerged (Figure 1).

\subsection{Londrina-Paraná}

The pattern of emergence flow of volunteer corn when propagules were deposited on the soil surface (T1-T4) indicates that the highest density of volunteer plants was found at the first week of August, with a subsequent decrease over the evaluation period (Figure 5). Loose grains (T4) and broken ears (T3) were the propagules that provided the highest density of volunteer plants. Ears with whole (T1) or half husk (T2) did not contribute effectively to the emergence of plants.
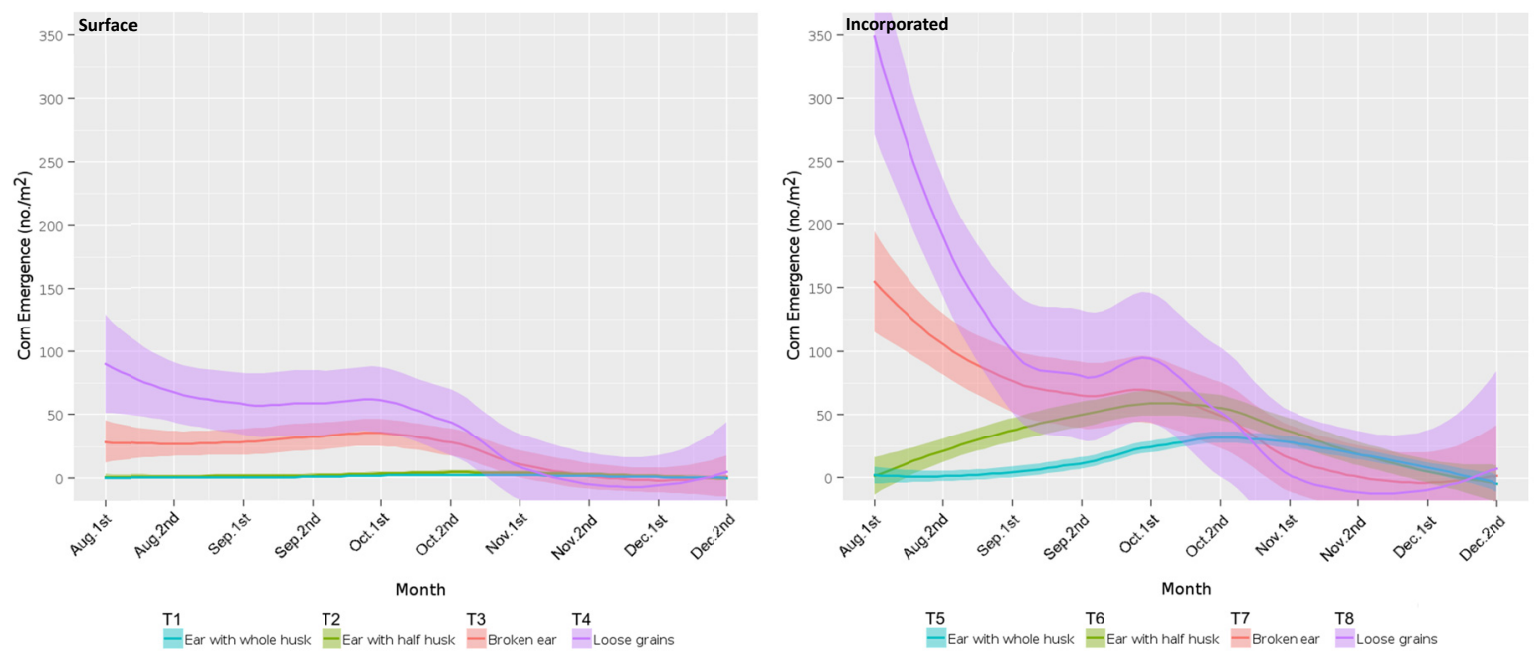

Figure 5. Dynamics of the emergence flux of volunteer corn, mean of 2013 and 2014, as function of both the disposition in soil (on surface, or partially incorporated) and the type of harvest loss. Londrina-PR, Brazil. 95\% confidence intervals are presented

The intense initial flux of volunteer corn right after the harvest and the lack of control measures of volunteer corn during the off-season period foment the proliferation of insect pests that can affect the crop grown in succession. Krupke et al. (2009) observed that the difference in the level of damage caused by Diabrotica virgifera in the roots of volunteer corn in Bt-positive and Bt-negative plants, raised the hypothesis that volunteer plants express lower concentrations of Bt protein than parent hybrids. Lower protein expression may accelerate the breakdown of Bt resistance due to the selection of resistant biotypes (Krupke et al., 2009).

When propagules were incorporated into the soil surface layer (T5-T8), an increased density of emerged plants was found as compared to when they were left on soil surface (Figure 5), similar to what was observed for the Cerrado area (Figure 1). Such behavior may relate to the more intense protection of the seeds against climatic instabilities, leading to longer viability of the embryo. Emergence peaks from loose grains (T8) and broken ears (T7) were higher in the initial period of evaluation, with subsequent decrease over time. However, ears with whole (T5) and half husks (T6) generated later emergence peaks (Figure 5). This pattern indicates that whole ears tend to be a problem mainly after soybean sowing due to its later emergence flow. According to previous results from López-Ovejero et al. (2016), under low infestations, control of volunteer corn originated from ears was consistently achieved by applying an ACCase inhibitor at the six trifolium stage of soybean. Two applications were recommended under higher levels of infestation, and, in such cases, the first application should be done at the third and the second application at the sixth trifolium stages of soybean.

The emergence distribution over time varied according to the position of the propagules in soil. When placed on soil surface, loose grains and broken ears were responsible for 64 and 32\%, respectively, of the total number of emerged plants, with only $4 \%$ of the total volunteer plants coming from whole ears, either with intact husk or not (Figure 6). When incorporated into the superficial layer of the soil, ears with either whole or half husks provided higher densities of emerged plants as compared to their correspondent disposition in soil surface. 

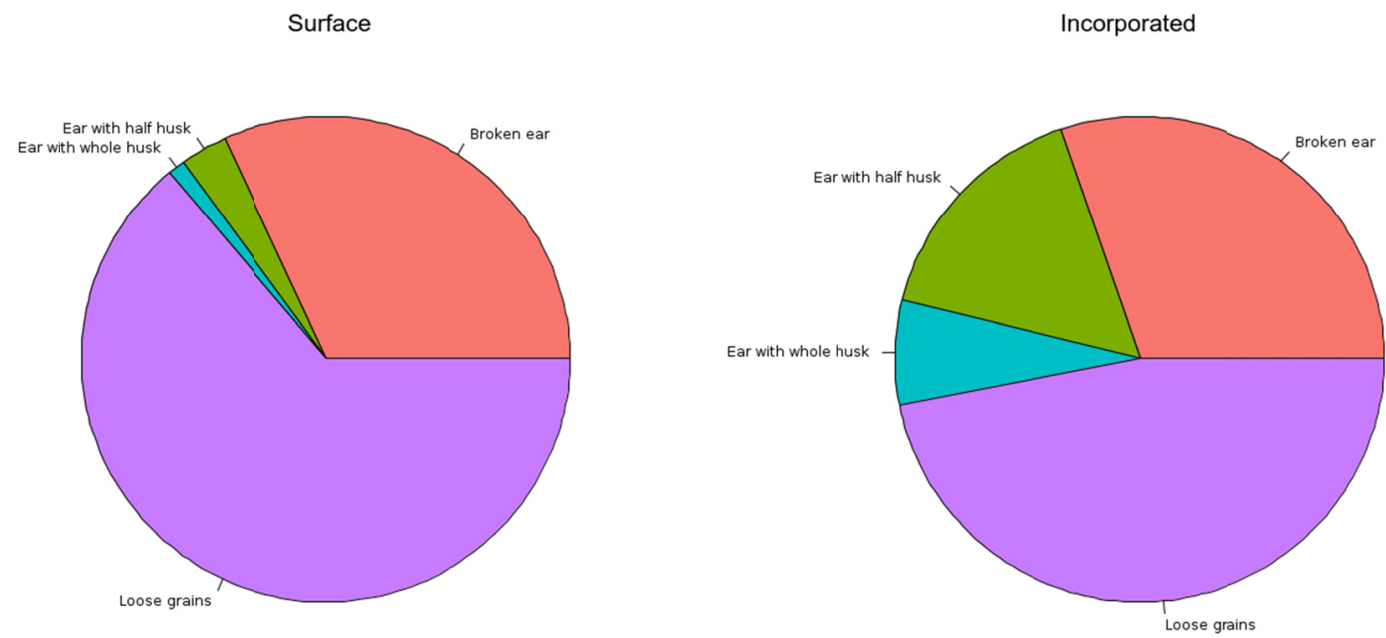

Figure 6. Mean proportion of volunteer corn seedlings, as function of both the disposition in soil (on surface, or partially incorporated) and the type of harvest loss. Londrina-PR, Brazil

Differential emergence patterns based on propagule position in soil is mainly explained by the closer contact of grains adhered to the ears with soil moisture, when they are incorporated. Therefore, it is expected that soil tillage will aggravate the problem with volunteer plants, since the increased seedling emergence rate from ears is combined with infestation from other sources (broken ears, loose grains). Chahal and Jhala (2016) reports volunteer corn emerge from depths of up to $15 \mathrm{~cm}$, which is a common depth for soil tillage practices.

The density of emerged plants in 2014 was higher than in 2013 (Figure 7). In general, the emergence flow pattern between years was similar, characterized by two typical peaks, the first in early August and the second along the first half of October. The later emergence peak is associated to the emergence of volunteer plants coming from ears in response to the combined effect of rainfalls and increasing temperatures, as previously discussed. The results corroborate with those observed in other field studies, where the control of volunteer corn plants coming from ears are considered trickier, due to delayed and successive emergence flows, as compared to grains detached from ears (López-Ovejero et al., 2016).

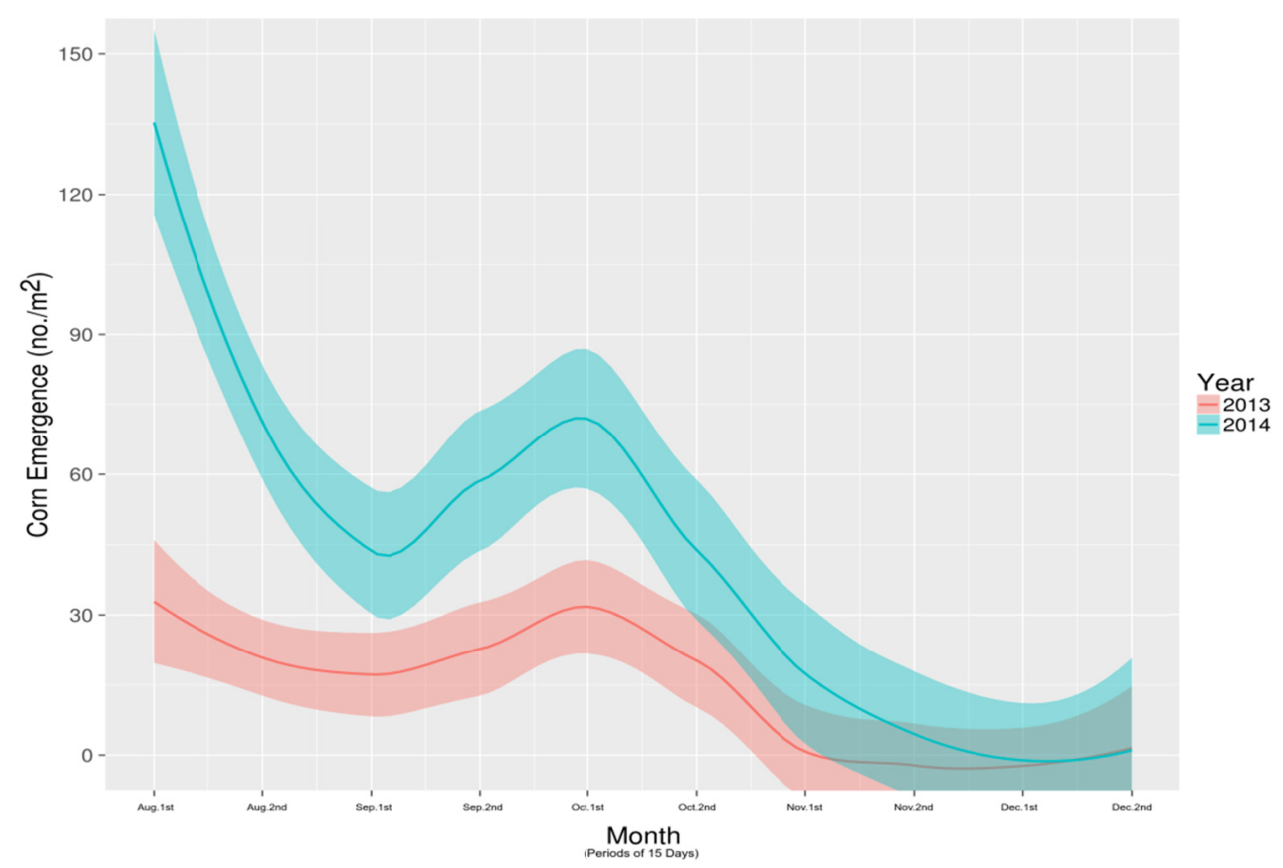

Figure 7. Dynamics of the emergence flux of volunteer corn, by year. Means of the disposition in soil and the type of harvest loss. Londrina-PR, Brazil. 95\% confidence intervals are presented 
The observation of climatic conditions (Figure 8) indicate that 2014 was characterized by higher temperatures at the beginning of August compared to 2013, what may have contributed to the more intense emergence flow of volunteer corn when analyzed together with precipitation - the highest volume of rainfall also occurred at this period of the year. These two variables may have contributed to the higher initial emergence flow, since air humidity was not restrictive (Figure 8).

In Londrina, the conditions in the fallow period between corn harvest and soybean sowing are characterized by mild temperatures associated with scattered rainfalls, which may stimulate the germination of corn seeds shortly after harvest. Therefore, in subtropical climate conditions similar to those in Paraná, the emergence of volunteer plants is maximized in years when the cold temperatures in this period are not so intense, despite this condition is associated with high rainfall or not (Figure 8).
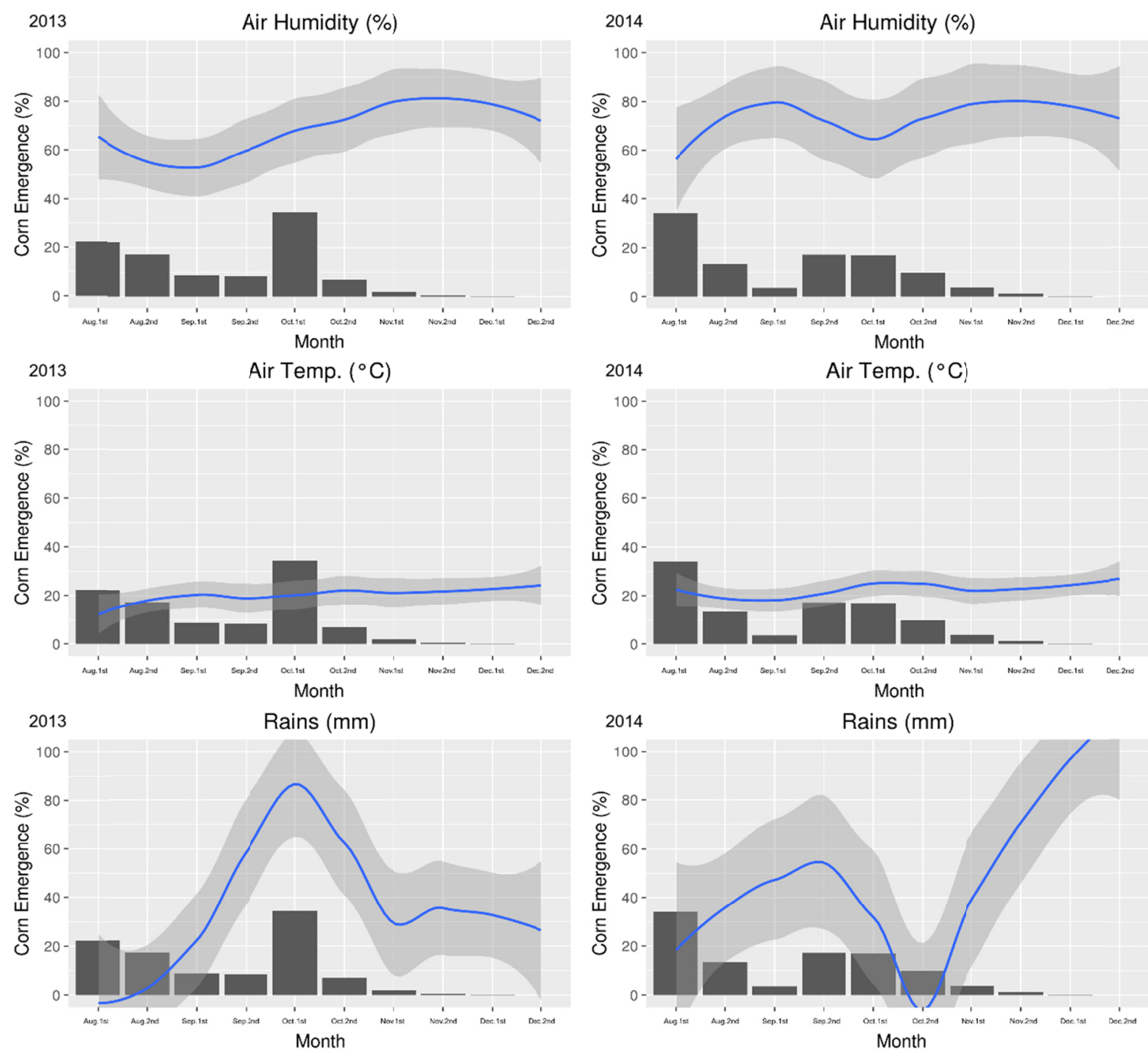

Figure 8. Dynamics of the emergence flux of volunteer corn (-bars), by year, as function of the environmental parameter. Means of the disposition in soil and the type of harvest loss. The behavior of the environmental parameter for the year is presented by a regression smoothed by the Loess method, with a 95\% confidence interval obtained from the 10-day period for every data of the graph (three points of mean data per month). Londrina-PR, Brazil

Summarizing, when partially incorporated into soil, propagules from corn harvest losses result in an increased density of emerged plants as compared to when they are deposited on soil surface. The main sources of volunteer 
corn infestation can be ranked in the following descending order of importance: (1) loose grains, (2) broken ears, (3) ears with damaged husk and (4) ears with intact husk. Ears present later emergence flows. Climatic conditions influence the emergence pattern of volunteer corn. For the Cerrado climate, the onset of the rainy season is preponderant for the beginning of the emergence start. Under subtropical climate conditions, mild cold temperatures, whether or not this condition is associated with intense rainfall, determines the main peaks of emergence.

\section{References}

Alms, J., Moechnig, M., Vos, D., \& Clay, S. A. (2016). Yield loss and management of volunteer corn in soybean. Weed Technology, 30, 254-262. https://doi.org/10.1614/WT-D-15-00096.1

Busari, M. A., Kukal, S. S., Kaur, A., Bhatt, R., \& Dulazi, A. A. (2015). Conservation tillage impacts on soil, crop and the environment. International Soil and Water Conservation Research, 3(2), 119-129. https://doi.org/10.1016/j.iswcr.2015.05.002

Chahal, P. S., \& Jhala, A. J. (2016). Impact of glyphosate-resistant volunteer corn (Zea mays L.) density, control timing, and late-season emergence on yield of glyphosate-resistant soybean (Glycine max L.). Crop Protection, 81, 38-42. https://doi.org/10.1016/j.cropro.2015.11.015

Chahal, P. S., Kruger, G., Blanco-Canqui, H., \& Jhala, A. J. (2014). Efficacy of pre-emergence and post-emergence soybean herbicides for control of glufosinate, glyphosate, and imidazolinone-resistant volunteer corn. Journal of Agricultural Science, 6, 131-140. https://doi.org/10.5539/jas.v6n8p131

Cleveland, W. S., \& Devlin, S. J. (1998). Locally weighted regression: An approach to regression analysis by local fitting. Journal of American Statistic Association, 83, 596-610. https://doi.org/10.2307/2289282

Cumming, G., Fidler, F., \& Vaux, D. L. (2007). Error bars in experimental biology. Journal of Cell Biology, 177, 7-11. https://doi.org/10.1083/jcb.200611141

Deen, W., Hamill, A., Shropshire, C., Soltani, N., \& Sikkema, P. H. (2006). Control of volunteer glyphosate-resistant corn (Zea mays) in glyphosate-resistant soybean (Glycine max). Weed Technology, 20, 261-266. https://doi.org/10.1614/WT-02-128.1

Krupke, C., Marquat, P., Johnson, W., Weller, S., \& Condley, S. P. (2009). Volunteer corn presents new challenges for insect resistance management. Agronomy Journal, 101, 797-799. https://doi.org/10.2134/ agronj2008.0149Nx

López-Ovejero, R. F., Soares, D. J., Oliveira, N. C., Kawaguchi, I. T., Berger, G. U., Carvalho, S. J. P., \& Christoffoleti, P. J. (2016). Interferência e controle de milho voluntário tolerante ao glifosato na cultura da soja. Pesquisa Agropecuária Brasileira, 51, 340-347. https://doi.org/10.1590/S0100-204X2016000400006

Marquardt, P., Krupke, C., \& Johnson, W. G. (2012). Competition of transgenic volunteer corn with soybean and the effect ton western corn root worm emergence. Weed Science, 60, 193-198. https://doi.org/10.1614/ WS-D-11-00219.1

Petter, F. A., Sima, V. M., Fraporti, M. B., Pereira, C. S., Procópio, S. O., \& Silva, A. F. (2015). Volunteer RR ${ }^{\circledR}$ corn management in Roundup Ready ${ }^{\circledR}$ soybean-corn succession system. Planta Daninha, 33, 119-128. https://doi.org/10.1590/S0100-83582015000100014

R Core Team. (2016). R: A language and environment for statistical computing. Vienna: R Foundation for Statistical Computing.

Silva, D. M., Bueno, A. F., Andrade, K., Stecca, C. S., Neves, P. M. O. J., \& Oliveira, M. C. N. (2017). Biology and nutrition of Spodoptera frugiperda (Lepidoptera: Noctuidae) fed on different food sources. Scientia Agricola, 74(1), 18-31. https://doi.org/10.1590/1678-992x-2015-0160

Souza, A. P., Mota, L. L., Zamadei, T., Martin, C. C., Almeida, F. T., \& Paulino, J. (2013). Classificação ckimática e balanço hídrico climatológico no estado de Mato Grosso. Nativa, 1(1), 34-43. https://doi.org/10.14583/2318-7670.v01n01a07

\section{Copyrights}

Copyright for this article is retained by the author(s), with first publication rights granted to the journal.

This is an open-access article distributed under the terms and conditions of the Creative Commons Attribution license (http://creativecommons.org/licenses/by/4.0/). 